\title{
Gender Issues in Juvenile Justice
}

\author{
Rosemary C. Sarri
}

The federal JJDP legislation has had a differential impact on the pattern of admission of females and males to detention facilities and training schools, and also on the rate of admission relative to the total available youth population. These findings suggest a differential societal response, and also variable incidence of delinquency among females and males. Data from a self-report survey of high school youth corroborate the latter assumption and also findings that have been noted by others. Attachment to parents and normative institutions is an important constraint on delinquent behavior, but this bonding interacts differently for females and males. Thus, both explanatory and intervention theories of delinquency need to consider gender as a critical variable.

Interest in gender differences in the type and frequency of crime as well as differences in the ways in which males and females are processed by justice system agencies has grown significantly in the past decade. ${ }^{1}$ This change is only one consequence of numerous other social and policy changes affecting women and men in this society. Recently, there has been a plethora of theoretical and descriptive statements attempting to explain similarities and differences in male-female criminal behavior, but systematic empirical research has lagged when compared with other criminal justice research. Nonetheless, the topic is now one of substantial interest to social scientists and policy makers.

Reports about changes in female roles appear to have had a significant impact on judges' and prosecutors' decisions because the incarceration of adult women has grown more rapidly in recent years despite the lack of evidence that there has been any increase in serious crime by females (Steffensmaier, Steffensmaier, and Rosenthal, 1979; Figueira-McDonough and Selo, 1980). In fact, during the first half of 1981, the number of women incarcerated in U.S. prisons grew at the rate of 22 percent a year-the largest gain since such statistics were first recorded in 1925. Although the overall rate of incarceration continues to grow rapidly in the United States and the total population of incarcerated males far exceeds the female population, the male growth rate during that same period was under 12 percent. Since female crime continues to be less serious than that of males and also less frequent, one can hypothesize that this disproportionate increase in social control is primarily a consequence

ROSEMARY C. SARRI: School of Social Work, The University of Michigan, Ann Arbor, Michigan.

Paper presented at the National Conference, "Rethinking Juvenile Justice" in Minneapolis, Minnesota, June 10, 1982. Conference sponsored by the Hubert Humphrey Institute of the University of Minnesota, the Northwest Area Foundation, and the Dayton-Hudson Foundation. 
of changes in the perception and actions of the critical decision makers in the criminal justice system, rather than a change in the behavior of the individuals who are the target of concern.

This paper examines some of the policy issues in juvenile justice in which gender is a significant factor by first reporting on findings from a longitudinal survey of adolescent youth in one metropolitan area. Second, findings about the processing patterns of the juvenile court in that same area will be considered. And lastly, we will report on the broader picture by examining national trends in deinstitutionalization in terms of the differential patterns for males and females. Although numerous efforts for juvenile justice reform were undertaken in the 1950s and 1960s, it was not until 1974 that the federal government was assigned substantial responsibility for effecting major policy and programmatic reform. Passage of the Juvenile Justice and Delinquency Act (PL93-415) in 1974 mandated the federal government to provide resources to the states for deinstitutionalization of certain classes of offenders, especially status offenders; for avoidance of the use of adult jails and secure detention as placement alternatives for those offenders; and for the development of community based programs. In 1977 and 1980, that statute was amended and strengthened in its innovative orientation toward detention and community based intervention. A priority was established for the removal of status offenders from secure confinement, for the reduction of detention, and for the elimination of jailing of juveniles. Because females disproportionately constitute the population of status offenders processed by the justice system, it could be hypothesized that this legislation would have a far more pronounced effect on females when measured in terms of incarceration in detention or public training schools.

The JJDP statute contained many laudatory approaches for innovations in juvenile delinquency control; but unfortunately, relatively small amounts of money were made available to the state, considering the goals that were sought. Therefore, the prediction of impact needs to be qualified relative to the amount of resources made available to achieve the goals. As Lerman has noted, far greater resources were available to the states through federal child welfare programs than from the Justice Department (Lerman, 1980). Moreover, foster care monies could be utilized for residential care. These latter funds interfered with the goal of the JJDP Act to deinstitutionalize delinquency programs because youth could readily be reclassified for the program with resources.

One of the most problematic aspects of the juvenile justice system is its failure to distinguish offenders from victims. Nowhere is this more true than in the case of sexual abuse and sexual behavior. Females are often identically handled for abuse and promiscuous behavior or prostitution. In a recent study of the handling of female offenders in Wisconsin, McIntosh and her colleagues reported that more than one-third of the adolescent females had been sexually abused (McIntosh and Jesudason, 1982). Fifty percent had been sexually assaulted and 66 percent reported attempting suicide. Most of the abused 
females did not seek assistance because of fear, embarrassment, or belief that nothing would be done to help them. Although they had been processed by social workers, few reported discussing these problems. They reported that most programs were concerned with control or with effecting a change in the female's personality or attitudes. These abused females reported punitive handling by the courts and difficulties in school and at home.

A second more recent federal policy initiative is also likely to have an impact on the operation of the juvenile justice system as it involves females. A series of special federal initiatives have been developed to curb and control adolescent pregnancy (U.S. Department of Health and Human Services, 1982). This legislation is important because sexual behavior has been one of the primary reasons for involvement of females in the juvenile justice system. Therefore, passage of the latter legislation provides an opportunity to learn of other policy and intervention approaches for dealing with this problem behavior. Unfortunately, however, the adolescent pregnancy legislation is primarily directed toward females and their families rather than equally toward males and females, despite the widely accepted fact that adolescent males are far more sexually active than are females. Nonetheless, this legislation, once again, points to the importance of gender as a critical variable in many social policy arenas. Young women and men come to the attention of the law in different ways; and once in the criminal justice system, they receive different treatment.

Contrary to popular belief, the law does not deal more benignly with females than with males. Hindelang recently noted in his analysis of the National Crime Survey that women were less often arrested because they in fact committed less crime than did males and also because the types of crime which they committed frequently were substantially less serious (Hindelang, 1979). He asserted that social theorists should accept these male/female differences as real and incorporate the sex variable into existing and emergent theories. He further argued that the tendency of theorists of the $1950 \mathrm{~s}$ and 1960 s to restrict their theories to males, by design, represented a decision to focus on residual variants after sex had been controlled, and thereby these theorists missed an opportunity to include in their explanations a powerful predictor of differential involvement in criminal activity. Others have raised the possibility of legal double standards with particular attention to status offenses and many sexual behaviors. Datesman and Scarpitti have remarked, "the juvenile court has utilized its discretionary powers in the service of traditional sex roles... (It) ... appears to be less concerned with the protection of female offenders than the protection of the sexual status quo" (Datesman, Scarpitti, and Stephenson, 1975). Evidence for this assertion and similar comments are drawn from findings which show that (1) females are more likely than males to be referred for status offenses; and (2) once referred, they receive harsher treatment for those offenses than males receive for serious 
offenses (Sheldon, 1981; Feyerherm, 1981). In the past, the severity of the response often included longer periods of institutionalization for females than for males. These findings provided the basis for the development of the new policy which argued for the design of nontraditional alternatives for the processing of these status offenders in programs such as youth service bureaus, diversion, and alternative schools.

\section{GENDER DIFFERENCES IN DELINQUENT BEHAVIOR}

Substantial evidence can be accumulated in support of the assumption that much delinquent behavior is normative for most adolescents and that society's response must be one which controls that behavior without having negative secondary consequences. At present, heroic intervention in the face of relatively non-serious behavior often results in outcomes which are far more serious than the problems which the intervention was attempting to alleviate. Society can assume that adolescent youth are a population at risk because of their challenge to adult norms of behavior. They then can design policies which will aid socialization toward adulthood rather than hamper it.

An adequate theory of delinquency for effecting social policy requires attention to individual and social-structural level variables. We need to ascertain the sources of influence that shape and maintain adolescent attitudes, norms, and behaviors. From our perspective, adolescent subculture is defined in terms of behaviors that aim to challenge adult authority and are often imitations of adult roles that have been defined as illegitimate for adolescents. Such behavior is expressed as formal rebellion against adult authority which might be a necessary impetus for the achievement of adult autonomy. Many development theorists, in fact, argue that such rebelliousness is a requirement for normal maturation (Gold and Petronio, 1980). Therefore, the rise and generality of certain deviant behaviors during mid-adolescence can be interpreted in this light.

A second major element in ascertaining gender differences in delinquent behavior comes from assessment of the extent of sex bias in the legal control system. In order to assess that bias, one must have valid information about sex differentials in behavior. Because of the inadequacy of official statistics, selfreport and victim surveys are often utilized in conjunction with official statistics to arrive at a more valid assessment of delinquency. In the case of juveniles, however, we have had to rely more exclusively on self-report and official statistics because victim surveys do not cover the vast majority of juvenile delinquent behavior. Findings from these various studies continue to support the assumption that females are less involved in all delinquent behavior and participate in less serious crime than do males. There is little support for the assertion that females specialize in certain offenses, but rather they are differentiated by frequency and degree more than by the activities themselves. It is true, however, that females commit far fewer serious and violent crimes. In official reports, the magnitude of difference is smaller than in 
self-report data; and in the case of status offenses, official data contrasts sharply with self-reports (Hindelang, Hirschi, and Weis, 1979).

Even less consensus exists about the extent and direction of sex differentials in delinquency control. Except for status offenses, official records usually indicate some sex bias in favor of females, but relatively little is known about the interactions between race, class, and gender with respect to legal processing. Figueira-McDonough observed that when one controls for seriousness of offenses, females and males are handled similarly in the processing of serious crimes, but in the case of minor offenses, females are often dealt with more stringently (Figueira-McDonough, 1981). In fact, for several categories of status offenses (e.g., promiscuity, running away, incorrigibility), males are seldom ever apprehended although self-reports indicate at least equal levels of this behavior by males.

Burbeck's analysis of a national sample of adjudicated and committed delinquents was also informative (Burbeck, 1978). He examined the relationship between severity of sanction and seriousness of the offense for which the juvenile was committed. Severity of sanction was evaluated on a scale from 1 to 4 with institutional placement considered the most stringent sanction. For males, every increase in seriousness of the commitment offense was associated with .63 units of increase in sanction severity. For females, on the other hand, there was no correlation between commitment offense and severity of sanction. In both instances, the analysis of co-variance included examination of the effects of several independent variables on sanctioning severity, but no relationships were as marked as those for males and females.

In a recent study of 1735 students in nine public and parochial high schools in a midwestern metropolitan community, we examined gender and race similarities and differences in delinquent behavior and in processing by the juvenile justice system (Figueira-McDonough, Barton, and Sarri, 1981). Youth were interviewed twice-first when they were fifteen and in the tenth grade and again one year later at age sixteen. Police and court records were also analyzed in each of the reported communities in which the youth resided.

\section{SELF REPORTS OF DELINQUENT BEHAVIOR}

The findings of self-reported deviant behavior in our study are consistent with the findings of Hindelang, Gold, and Elliott. As can be observed in Table 1, about the same percentage of females and males have been involved in minor and status offenses with the exception of sexual behavior where frequency for males is much higher. Moreover, the high levels of involvement by all youth suggest that these behaviors can be considered as normative in this age group. All youth do not participate in all of these behaviors, but the majority report some involvement in one or more. We found that frequent peer involvement in a normative system which encourages such activities was associated with engaging in these behaviors. Far lower percentages reported serious 
Table 1. Male and Female Self-Reported Delinquent Involvement

\begin{tabular}{|c|c|c|c|c|c|c|}
\hline \multicolumn{4}{|c|}{ Percent Ever Committing } & \multicolumn{3}{|c|}{ Mean Frequency of Delinquent Involvement } \\
\hline & Males & Females & $\begin{array}{l}\text { Ratio } \\
M / F\end{array}$ & Males & Females & $\begin{array}{l}\text { Sig. Level Diff. } \\
\text { Male-Female }(T)\end{array}$ \\
\hline \multicolumn{7}{|l|}{ Status/Subcultural } \\
\hline Alcohol Use & 81.8 & 80.0 & 1.02 & 19.1 & 14.3 & $<.001$ \\
\hline Lied About Age & 65.0 & 59.0 & 1.10 & 8.8 & 5.1 & $<.001$ \\
\hline Loitered at School & 57.1 & 56.9 & 1.00 & 10.3 & 9.1 & - \\
\hline Marijuana Use & 48.3 & 48.3 & 1.00 & 12.2 & 10.6 & - \\
\hline Truancy & 48.0 & 47.1 & 1.02 & 4.9 & 4.9 & - \\
\hline Had Sex & 51.7 & 28.2 & 1.83 & 9.8 & 5.3 & $<.001$ \\
\hline Run Away & 6.4 & 6.9 & 0.93 & .2 & .1 & - \\
\hline \multicolumn{7}{|l|}{ Property } \\
\hline Theft $<\$ 5$ & 39.9 & 24.5 & 1.63 & 2.6 & 1.0 & - \\
\hline School Vandalism & 29.6 & 11.7 & 2.53 & 28.9 & 8.0 & $<.001$ \\
\hline Theft $\$ 5-\$ 50$ & 21.5 & 11.3 & 1.90 & 1.2 & .5 & $<.001$ \\
\hline Receiving Stolen Goods & 27.1 & 8.5 & 3.19 & 1.5 & .2 & $<.001$ \\
\hline$B \& E$ & 21.2 & 4.5 & 4.17 & .9 & .1 & $<.001$ \\
\hline Car Theft & 10.7 & 2.8 & 3.82 & 1.0 & .1 & $<.001$ \\
\hline Theft $\$ 50-\$ 500$ & 6.0 & 1.0 & 6.00 & .2 & .7 & - \\
\hline \multicolumn{7}{|l|}{ Fraudulent Use of Credit } \\
\hline Cards & 4.2 & 2.6 & 1.61 & .5 & .4 & - \\
\hline Theft $>\$ 500$ & 3.4 & 0.4 & 8.50 & .2 & .4 & .02 \\
\hline \multicolumn{7}{|l|}{ Person/Violent } \\
\hline Serious Fight & 32.1 & 9.2 & 3.49 & 1.3 & .3 & $<.001$ \\
\hline Concealed Weapon & 22.2 & 5.1 & 4.35 & 1.3 & .3 & $<.001$ \\
\hline Gang Fight & 27.2 & 19.0 & 1.43 & 1.3 & .9 & - \\
\hline Aggravated Assault & 11.6 & 3.9 & 2.97 & .5 & .3 & - \\
\hline Extortion & 11.8 & 3.9 & 3.03 & 1.0 & .3 & .001 \\
\hline Hit Parents & 8.7 & 9.4 & 0.93 & .4 & .7 & - \\
\hline Use Weapon & 6.0 & 1.8 & 3.33 & .7 & .4 & $<.001$ \\
\hline Sexual Assault & 4.8 & 3.3 & 1.46 & .7 & .2 & - \\
\hline Hit Teacher & 6.6 & 1.6 & 4.13 & 1.0 & .8 & $<.001$ \\
\hline \multicolumn{7}{|l|}{ Other } \\
\hline Selling Drugs & 25.3 & 14.2 & 1.78 & 4.4 & 1.5 & $<.001$ \\
\hline Driving Intoxicated & 31.0 & 14.9 & 2.08 & 5.8 & 2.0 & $<.001$ \\
\hline Hard Drugs & 11.9 & 10.0 & 1.19 & 1.7 & 1.0 & .03 \\
\hline Prostitution & 4.7 & 0.2 & 23.5 & .9 & .1 & $<.001$ \\
\hline$N$ (in range) & $0-905)$ & (15-826) & & & & \\
\hline
\end{tabular}


delinquencies such as assault, robbery, or other major crimes; and these latter were substantially more likely to be committed by males than females. Crimes such as burglary, theft, vandalism, fighting and assault, extortion, robbery, and rape were reported by between five and 30 percent of the youth. The number of serious person crimes was extremely small (between one and two percent) which is not dissimilar to other national data. It should be born in mind that this sample was interviewed at an age when serious delinquency is relatively high.

Among the more serious crimes, involvement decreased for males and females but the male/female ratios increased. In the instance of burglary, 21.5 percent of the boys reported at least one breaking and entering as compared with only 4.5 percent of the girls (ratio of 4.71). The mean frequency of commitment of the various offenses, also given in Table 1, shows substantial variation by gender. For 18 out of 29 behaviors, these differences are significant.

We also inquired about other types of illegal activity such as driving while intoxicated, selling drugs, and prostitution; and here too, relatively small proportions of youth reported engaging in such behaviors. Thus, except for the use of alcohol and marijuana and hitting parents, females were less delinquent than were males, both in seriousness and in frequency of delinquent behavior. We do not have evidence for the assertion of gender specializations in minor types of delinquent behavior, but rather the evidence supports the general finding of lower levels of crime of all types by females, and particularly far lower incidence of serious crime.

Because many have asserted that female criminal behavior is increasing, we wished to check our findings with those of an earlier study. Hindelang's survey, completed in the late 1960 's, enabled us to do just that, although not all behavioral items compared exactly (Hindelang, 1973). The findings in Table 2 reveal that among the subcultural items (the first five) there has been an increase in male involvement and an even greater increase in female involvement. This change is particularly apparent where one compares the ratios for the two periods. Whereas adolescent minor crime used to be primarily male, it now includes both boys and girls in similar percentages. However, there is little evidence to support the claim of greater involvement among girls in aggressive or more serious property offenses.

\section{Parental Relationships}

A prevailing generalization is that pre-adolescent and adolescent youth move away from parents and toward peers as their primary reference group. Many research findings appear to support the view that peer influences peak during this period of time and that parental and peer influences are negatively correlated (Curtis, 1975). However, Brittain and others have more recently observed that adolescents tend to refer to peers in situations that have implications for their current status and identity and to parents in situations that have implications for their future status and roles (Brittain, 1963). Our 
Table 2. Comparison Between the Late 60s (Hindelang) and the Late 70s (Sarri/McDonough) of Selected Items of Self-Reported Delinquency

\begin{tabular}{|c|c|c|c|c|c|c|}
\hline \multirow[b]{2}{*}{ Corresponding } & \multicolumn{3}{|c|}{ Percent Ever Committing } & & \multicolumn{2}{|c|}{ Ratios } \\
\hline & & & & & \multirow{3}{*}{$60 s$} & \multirow{3}{*}{$70 \mathrm{~s}$} \\
\hline \multirow{2}{*}{ Crime Categories } & \multicolumn{2}{|c|}{ Males } & \multicolumn{2}{|c|}{ Females } & & \\
\hline & Late $60 \mathrm{~s}$ & Late $70 \mathrm{~s}$ & Late $60 \mathrm{~s}$ & Late $70 \mathrm{~s}$ & & \\
\hline Use Alcohol & 63.6 & 81.8 & 42.8 & 80.0 & 1.48 & 1.02 \\
\hline Marijuana & 26.2 & 48.3 & 14.5 & 48.3 & 1.80 & 1.00 \\
\hline Truancy & 40.5 & 48.0 & 24.8 & 47.1 & 1.63 & 1.02 \\
\hline Sex & 58.2 & 51.7 & 11.9 & 28.1 & 4.86 & 1.83 \\
\hline Drunk Driving & 21.2 & 31.0 & 6.4 & 14.9 & 3.33 & 2.08 \\
\hline Extortion & 9.5 & 11.8 & 3.2 & 3.9 & 3.00 & 3.03 \\
\hline
\end{tabular}

Similar But

Non-Corresponding

Crime Categories

THEFT

Theft $<\$ 10$

Theft $>\$ 10$

\begin{tabular}{crrllrr}
\multicolumn{2}{c}{ Late $60 \mathrm{~s}$} & & & \multicolumn{3}{c}{ Late $70 s$} \\
$M$ & $F$ & $R$ & & \multicolumn{1}{c}{$M$} & $F$ & $R$ \\
53.4 & 26.3 & 2.03 & Theft $<\$ 5$ & 39.9 & 24.5 & 1.63 \\
19.0 & 4.6 & 4.15 & Theft $\$ 5-50$ & 27.5 & 11.3 & 1.90 \\
& & & Theft $\$ 50-500$ & 6.0 & 1.0 & 6.00 \\
& & & Theft $>\$ 500$ & 3.4 & .04 & 8.50
\end{tabular}

FIGHTS

Fist Fight

Weapon Fight

$56.6 \quad 21.6$

11.1

21.6

2.58 Serious Fight

32.1

9.2

3.49

Gang Fist Fight

25.8

4.1
6.3

2.70

Gang Weapons Fight

$8.5 \quad 2.9$

4.11 Gang Fight

$27.2 \quad 19.0$

1.43

*This item was differently worded in the two studies. In our study the question referred to having sex with someone of the opposite sex. In Hindelang's, the only sexual behavior item was promiscuous sexual behavior.

findings indicated that parental attachment had both direct and indirect effect on delinquency norms and behavior, thus providing some support for the Brittain hypotheses. In several areas of behavior, its importance was greater than that of peers. Youth who reported close attachments to parents who disapproved of delinquent behavior were themselves less delinquent. In the case of females, this influence was even greater. The more females perceived that parents disapproved of delinquency, regardless of their own norms, the more those who were close to their parents seemed to shy away from delinquency. When one therefore considers that substantial numbers of females are referred to the juvenile court because of family disruption, these data take on new meaning for staff and others working with adolescent females and their families. For males, the effect of perceived parental norms was less and was mediated through parental attachments as well as their own norms. 
Boys who perceived parental norms as disapproving were more likely to report a closer attachment to parents and to report that they also disapproved of delinquent behaviors. But, while boys who were more concerned with parental approval were more likely to report disapproving norms, these norms did not result in lower delinquent behavior.

Overall, the findings clearly indicate that intervention approaches need to take parental relationships into consideration. About half of the youth reported positive relationships with their parents, although as expected, far lower levels of identification with parents were observed when they were asked if they would like to be like their mothers or fathers. Although there was some indication that relationships were more positive with mothers than with fathers, patterns of identification were closer for the same sex parent.

\section{School Attachment}

Attachment to school was a strong inhibitor of delinquency for females, but had relatively little effect on males unless it was coupled with other variables. Overall, the majority of youth were positive toward their school experience and their attitudes grew more positive as they grew older, but this may partly be due to the fact that youth with more negative attitudes were likely to have dropped out of school by the end of their junior year. The vast majority of youth had high aspirations with respect to post-secondary education, and most desired an interesting job more than material resources. Gender differences were apparent with respect to aspirations in that males tended to place more value on material resources.

Overall, youth encounters with the law changed little from year to year, our research indicated, but they were far higher than would be deemed necessary or desirable. More males than females reported such contacts: 30 percent of the females reported being stopped by police at least once during the year, whereas the comparable statistic for males was 60 percent. Seventeen percent of the males and six percent of the females said that they had been referred at least once to juvenile court during the year. Twenty-one percent of the males and 13 percent of the females had been suspended from school at least once. Clearly, they reported a high level of contact with the law.

\section{JUVENILE COURT PROCESSING}

Part of this study also involved an examination of processing by the juvenile court and by police in this particular county. Information from the court included the following:

(1) Approximately 12 percent of the youth from these schools had some contact with the juvenile court-not significantly different from other youth reports or other studies, but the percentage of youth processed varied greatly by school from two percent in one school to as high as 17 percent in the school with the highest rate. 
(2) Over 80 percent referred to the court were male and 20 percent were reported to be non-white. However, the juvenile court lacked data on race for 56 percent of the youth, so the race data are not reliable.

(3) Offenses for which youth were processed to the court included the following: larceny 26 percent; burglary 16 percent; truancy 11 percent; assault five percent; other 42 percent.

(4) Females were generally younger than males and were referred overwhelmingly for status offenses and larceny. Most referrals originated with the police ( 70 percent) although 11 percent were referred by schools, seven percent by business and five percent by parents. Females were more often referred by parents and businesses with notable race differences. Blacks tended to be referred more often by police and businesses and for more serious charges.

(5) Of all the youth referred to the court, 60 percent of the cases were dismissed or diverted early in the processing, with white males having the best chance for dismissal; white females for diversion; black females for probation; and black males for the most formal processing and the severest sanctions. Non-whites tended to be somewhat older than were white youth and were most often processed for property crimes. The findings on gender differences in processing correspond to those in a recent study completed by Alder and Polk (1981) in Oregon.

(6) Given the fact that vast differences were observed in the rate of referral by school and the type of behavior that brought referral, it wasn't surprising to observe that there were substantial differences in disposition. Black youth, particularly males, tended to receive the severest sanctions and middle class white youth were far more often referred to their parents and to private treatment agencies.

Our longitudinal study did not follow youth through adjudication and commitment, but analysis of some of the national data from Children in Custody enables one to ascertain gender differences over the decade of the 1970's (U.S. Bureau of the Census, 1982). Analysis of information on the placement of juveniles in detention is particularly useful in illuminating some of these patterns.

\section{IUVENILES IN DETENTION}

One of the most problematic aspects of juvenile justice is the detention of youth in juvenile detention facilities and in adult jails. Analysis of population distribution in juvenile justice indicates that in any year, nine out of ten youth processed by residential facilities in the juvenile justice system will be found in detention units of adult jails (Sarri, 1974). It is estimated that nearly one million youth spend one or more days in a lock-up jail or detention in the United States each year. Comprehensive information about detention practices has been lacking until recently, because most of these programs are operated under local control and very few systematic studies have been completed. However, the 
monitoring provisions of the Juvenile Justice and Delinquency Prevention Act greatly increased the accumulation of routine information about the detention and jailing of youth. Unfortunately, there are still substantial interstate variations in code provisions and in governmental information processing so that comparison across states must always be viewed in terms of relative variations. It is advisable to observe patterns over time in making comparisons among the states.

When one examines the other area of detention, namely the actual placement of children and youth in facilities where they will be held prior to trial, the results are equally problematic. About 20 percent of all court referrals are held in detention in any given year-nearly double the recommended national standard of ten percent. Approximately one half million youth are held in detention, and this number has not declined relative to the decline in youth population during the past decade despite sustained efforts from the legislation. In the case of detention, it clearly seems to be the case that the availability of beds in institutions means that those beds will be filled by youth. A small number of states have a large number of detention facilities; and thus, it is not surprising that five states alone have more than fifty percent of the youth held in public detention. For example, the rate of detention in California is 4734 per 100,000 juveniles as contrasted with 44 in the state of North Dakota, or a difference of approximately 100 times. Overall, the rate of detention nationally was 157 in 1979, and that was a substantially lower rate of detention than we had had during the decade. But when both public and private facilities are considered together, the decline is estimated to be considerably less. Variability within and across jurisdictions in states remains as one of the most significant characteristics of detention practice. This variability is of longstanding duration as considerable research has demonstrated (Rubin, 1980; Poulin, et al., 1980; Sarri and Hasenfeld, 1976). Nearly 60 percent of the admissions occur in five states where less than 20 percent of the population resides. In attempting to ascertain reasons for this persistence of practice and variability among states, a number of factors appear to be influential in decision making. State rates of admission to detention facilities are correlated with the degree of urbanization, number of detention centers, and rates of referrals to the courts; whereas the rate of jailing is correlated with rates of arrest, particularly for status offenses. Offense behavior influences detention practice, but not always in the expected direction because seriousness of offense is less important than are sex, race, and family characteristics. Having a prior record increases substantially the likelihood of placement regardless of charge.

\section{GENDER DIFFERENCES IN DEINSTITUTIONALIZATION}

Analysis of gender differences in detention before and after the passage of the JJDP Act provides an excellent opportunity to evaluate several important 
Table 3. Juvenile Admissions to Public Institutions, 1971, 1974 and 1979*

\begin{tabular}{lcccccc}
\hline ADMISSIONS & \multicolumn{2}{c}{1971} & \multicolumn{2}{c}{1974} & \multicolumn{2}{c}{1979} \\
\hline Detention & Number & Percent & Number & Percent & Number & Percent \\
\hline Females & 147,119 & 30 & 157,850 & 30 & 95,643 & 21 \\
Males & 349,407 & 70 & $\frac{371,225}{20}$ & 70 & $\frac{356,167}{49}$ & 79 \\
$\quad$ TOTAL & 496,526 & & 529,075 & & 451,810 &
\end{tabular}

Training Schools

\begin{tabular}{|c|c|c|c|c|c|}
\hline Females & 14,686 & 22 & 13,669 & 20 & 8,444 \\
\hline Males & 53,089 & 78 & 53,737 & 80 & 56,972 \\
\hline TOTAL & 67,775 & & 67,406 & & 65,416 \\
\hline
\end{tabular}

*Source: U.S. Bureau of Census, Children in Custody.

elements of the Act. Table 3 reveals a substantial drop in female admissions to public detention facilities between 1971 and 1979, but most of that decline occurred after passage of the Act in 1974. There was a decline of 51,476 admissions or a change of 32 percent. In contrast, male admissions increased between 1971 and 1974 by 32,549 admissions and then declined significantly. Overall, however, the percent change for males between 1971 and 1979 was an increase of 6.4 percent. These changes are also apparent in the observation that 30 percent of the admissions were female in 1971 and 1974, but only 21 percent were female in 1979.

Admissions to training schools show similar patterns to those observed for detention, although the numbers admitted were far fewer, as would be anticipated. In 1971, 22 percent of the training school admissions were female; and in 1979, that figure had declined to 13 percent. There was no change in the percentage of detention admissions relative to training school admissions. Approximately 15 percent of the male detention admissions are reflected in training school admissions in both 1971 and 1979. For females, nine percent of detention admissions are reflected in training school admissions. Clearly, the vast majority of youth held in detention do not end up committed to training schools, as others have noted.

Between 1971 and 1979, the eligible youth population (10-18 years) in the United States declined from 30 million to 28.7 million. Thus, the decline in detention admissions of females exceeded the decline in the youth eligible population. During that same period, juvenile arrests increased by 15 percent (18.7 for males and 10.8 for females). We cannot ascertain whether this increase was associated with detention practices, but it appears not to have 
Table 4. Census of Juveniles in Public Detention Centers in 1966, 1971, 1974 and 1979

\begin{tabular}{cccccccc}
\hline Year & Number of Units & \multicolumn{2}{c}{ Numberof Juveniles } & \multicolumn{4}{c}{ Rate per 100,000 } \\
\hline & & Males & Females & $\%$ Female & Male & Female & Total \\
& & & & & & & \\
\hline 1966 & 242 & 7151 & 3248 & 30 & 51.7 & 26.3 & 35.3 \\
1971 & 305 & 7912 & 3836 & 33 & 50.5 & 25.4 & 38.2 \\
1974 & 331 & 7698 & 3312 & 30 & 50.6 & 22.1 & 37.7 \\
1979 & 438 & 8230 & 3278 & 28 & 56.7 & 23.4 & 40.3 \\
\hline
\end{tabular}

Sources: U.S. Department of Justice, Children in Custody Reports for 1971, 1975, 1979, Washington, D.C.: NCJISS, 1980.

D. Pappenfort, D. Kilpatrick, and A. Kuby, A Survey of Children's Residential Institutions, 1966, Chicago: University of Chicago School of Social Service Administration, 1970, pp. 4-5.

Rates were calculated for the youth population 10-18 years old. See U.S. Census Current Population Reports Series, p. 25.

These data reflect the number of youth in detention facilities oan a specific date in each of the above years, usually June 30 .

been a significant factor. Thus, there is reason to argue that the JJDP Act implementation may well have contributed to the decline in female admissions since females are more likely to have been status offenders who were a special target of the Act. Obviously, state variations in detention need to be studied further, because it is probable that the Act had a significant impact in some states and little or no impact in others. The recent evaluations of the changes effected following the major revision of the juvenile code in Washington state indicate that much variation should be expected. If we consider state variations between 1971 and 1979 for females, three patterns emerge. In thirteen states, female admissions steadily increased-in numerous instances by several hundred percent. In fifteen states, female admissions steadily declined and again the decline was often very large. Variability over time characterized admissions in the remaining seventeen states which reported youth in detention. There were six states which reported no youth held in public detention facilities, but all of these states held juveniles in private facilities, special units of training schools, or in adult jails.

Another method for ascertaining change in detention practice is to examine the daily census. Table 4 presents the detention censuses in each of the years under consideration and reveals some interesting contrasts to the patterns observed in the study of admissions. The number of detention facilities increased by nearly 80 percent since 1966 with most of the growth between 1971 and 1979 . The eligible youth population declined by nearly 18 percent between 1966 and 1979, so this clearly was not the cause of the increase in facilities. 
The numbers of youth in detention remained remarkably stable between 1966 and 1979: 10,875 in 1966 and 11,508 in 1979. However, the rate of eligible youth in detention steadily increased from 35.3 per 100,000 in 1966 to 40.3 in 1979. Overall, the female rate declined from 26.3 to 23.4 whereas the male rate increased substantially from 51.7 to 56.7 . Complete data on length of stay are not available, but those which are suggest that average length of stay in detention increased from 12 to 15.5 days. Once again the hypothesis is corroborated that if facilities are available, they will be used. In this instance males were at far greater risk for institutional commitment than were females.

Thus far we have only considered the probable impact of the JJDP Act on detention practices. During this same time period, there were numerous Supreme Court and state court decisions which should have resulted in far greater declines in detention than were observed. Organizational and community constraints are powerful factors inhibiting innovation and change in juvenile justice as in other areas. In the case of detention, less positive change occurred for males overall; but when one considers the arrest rate of females and the types of crime and misbehavior for which they are arrested and detained, females have not really benefited any more than have males.

Accountability in detention decision making is lacking in many jurisdictions. Some courts do not keep any detention information. Thus, they do not know the systematic biases that may be operative, nor do they have the data necessary for any type of program evaluation. Overuse and inappropriate use of detention can be reduced if adequate information is known about who is being held, how long, and for what reasons. Seriousness of the charged offense is seldom a basis for differentiating between detainees and nondetainees. Obviously, youth, particularly females who have no home or whose parents refuse to accept responsibility for them, run the highest risk of detention, regardless of what they have or have not done. Police are reluctant to release youth on the street once there has been an apprehension, regardless of the offense charged.

\section{CONCLUSIONS}

This paper makes no attempt to assess the overall impact of the Juvenile Justice and Delinquency Prevention Act, but rather it examines some of the areas where its impact might have had differential impact on males and females. Reduction of secure detention was one of the principal targets of this act; moreover, this area is critical because experience in detention or jail has the most profound impact on the largest number of youth processed through the juvenile justice system each year. The results of our examination to date indicate that far less has been achieved than was expected.

United States society is casting a very wide net, exerting social control more broadly than many consider necessary or desirable in a democratic nation given what we know about the effectiveness of correctional intervention. The 
percentage of the youth population being handled through the juvenile justice system has increased in most states since 1965 despite the decline in juvenile crime rates in recent years and the significant decline in the eligible youth population. Some assert that the greater allocation of resources to the justice sector has permitted the system to expand while others argue that youth unemployment, poor education, racism, sexism, and family disruption are factors producing this shift. In any event, crime rate changes appear to have little impact on expansion or contraction of the system.

The lack of legitimate social roles and economic opportunities for youth, females and males, in American society must be faced as one of the most critical social problems today if we are to resolve many of the difficulties faced by the juvenile justice system. Crime is a manifestation of powerlessness to a substantial degree, and youth face a dismal situation in this regard in the U.S. Without some relief in this area, the youth situation might well explode during the 1980s.

Minority and working class youth have been negatively impacted by the economic stagnation and lack of opportunity throughout the $1970 \mathrm{~s}$, and their response often has been one which is disapproved by the dominant adult society. In turn, society responds with even more punitive control and the cycle of negative interactions escalates.

It is clear that a few states have been partially successful in reducing the most negative aspects of the juvenile justice system, and have done so without placing their respective populations at greater risk. Strategies for the future might be more effective if there were more evaluation of the latter states to determine how they achieved their reductions. If another generation of youth is not to be harmed unnecessarily, greater parsimony in juvenile justice intervention and control for females and males must be achieved.

\section{REFERENCES}

ALDER, C. and K. POLK

1981 "Diversion and Hidden Sexism." Unpublished paper, University of Oregon, Department of Sociology, Eugene, OR. March.

BRITTAIN, C.

1963 "Adolescent Choice and Parent-Peer Cross Pressures." American Sociological Review, 28:385-391.

\section{BURBECK, T.}

1978 "Sex Discrimination in the Disposition of Incarcerated Juveniles." Ann Arbor, MI: University of Michigan Department of Sociology.

CURTIS, R. L.

1975 "Adolescent Orientations Toward Parents and Peers: Variations by Sex, Age and Socio-Economic Status." Adolescence, 10:483-494. 
DATESMAN, S., F. SCARPITTI and R. STEPHENSON

1975 "Female Delinquency: An Application of Self and Opportunity Theories." Journal of Research in Crime and Delinquency, 12(1): 107-123.

FEYERHERM, $W$.

1981 "Measuring Gender Differences in Delinquency: Self-Reports vs. Police Contact." In Warren, op. cit., 46-54.

FIGUEIRA-MCDONOUGH, J.

1981 "Court Process in Plainfield." Unpublished paper, Ann Arbor, MI, Insitute for Social Research, October.

FIGUEIRA-MCDONOUGH, J., W. BARTON and R. SARRI

1981 "Normal Deviance: Gender Similarities in Adolescent Subcultures" in $M$. Warren, op. cit., 17-45.

FIGUEIRA-MCDONOUGH, J. and E. SELO

1980 "A Reformulation of Equal Opportunity: Explanations of Female Delinquency." Crime and Delinquency, (July): 333-343.

GOLD, M. and R. PETRONIO

1980 "Delinquent Behavior in Adolescents" in J. Adelson, Handbook of Adolescent Psychology, New York: Wiley.

HINDELANG, MICHAEL

1973 "Age, Sex and the Veratility of Delinquent Involvement." Social Problems, 23 (Spring): 552-574.

HINDELANG, MICHAEL

1979 "Sex Differences in Criminal Activity." Social Problems, 27:143-156.

HINDELANG, MICHAEL, T. HIRSCHI, and J. WEIS

1979 "Correlates of Delinquency: The Illusion of Discrepancy Between Self-Report and Other Measures." American Sociology Review, 44(6): 995-1014.

LERMAN, P.

1980 "Trends and Issues in the Deinstitutionalization of Youth in Troble." Crime and Delinquency, 26(3):333-343.

MCINTOSH, M., P. WARNER, and V. JESUDASON

1982 "Female Offenders in Wisconsin, 1982." Looking Glass, 6(5):1-6.

POULIN, J., J. LEAVETT, T. YOUNG and D. PAPPENFORT

1980 Juveniles in Detention Centers and Jails: An Analysis of State Variations During the Mid 1970's. U. S. Department of Justice, LEAA Office of Juvenile Justice and Delinquency Prevention, Washington D.C.: U.S. Government Printing Office.

RUBIN, T. (Ed.)

1980 Juvenile Justice. Goodyear, Santa Monica, CA.

SARRI, R. C.

1974 Under Lock and Key: Juveniles in Detention and Jail. Ann Arbor, MI: National Assessment of Juvenile Corrections, December 1974. 
SARRI, R. C. and Y. HASENFELD

1976 Brought to Justice: Juveniles, the Courts and the Law. Ann Arbor, MI: National Assessment of Juvenile Corrections.

SHELDON, R.

1981 "Sex Discrimination in the Juvenile Justice System, Memphis Tenn. 1900-1917." in Warren, op. cit., 55-73.

STEFFENSMAIER, D. H., R. H. STEFFENSMAIER and A. S. ROSENTHAL

1979 "Trends in Female Violence." Sociological Focus, 12 (August): 217-227.

U. S. BUREAU OF THE CENSUS

1982 Children in Custody. Washington, D.C.: U.S. Government Printing Office. Surveys are available for six biennial national surveys administered by the U.S. Census Bureau to all known public juvenile correctional facilities. Institutions under private auspices were added to the census in 1974.

UNITED STATES DEPARTMENT OF HEALTH AND HUMAN SERVICES 1982 Programs in Adolescent Pregnancy and Family Life.

WARREN, M. (Ed.)

1981 Comparing Female and Male Offenders. Sage, Beverly Hills, CA. 